\title{
Inhaled nitric oxide in 2003: a review of its mechanisms of action
}

\author{
[L'inhalation de monoxyde d'azote en 2003 : une revue de ses mécanismes et de son action]
}

Tianlong Wang MD, Driss El Kebir PhD, Gilbert Blaise MD

Purpose: To review the pulmonary and systemic effects of endogenous nitric oxide and inhaled nitric oxide administered to patients.

Source: A systematic search for experimental data, human case reports, and randomized clinical trials since 1980, the year of discovery of endothelium-derived relaxing factor.

Principal findings: Nitric oxide has pulmonary and systemic effects. Inhaled nitric oxide not only causes selective pulmonary vasodilation but also results in pulmonary vasoconstriction of the vessels perfusing non-ventilated alveolae. The systemic effects of inhaled nitric oxide, which include modulation of the distribution of systemic blood flow, increase in renal output, interaction with coagulation, fibrinolysis and platelet functions, alteration of the inflammatory response, are described and the mechanisms of nitric oxide transport are explained. The possible toxicity of inhaled nitric oxide is also discussed.

Conclusion: The multiple effects of inhaled nitric oxide support its role as a pulmonary and extra-pulmonary medication.

Objectif : Revoir les effets pulmonaires et généraux de l'oxyde nitrique (NO) endogène et du NO inhalé, administré aux patients.

Source : Une recherche systématique de données expérimentales, d'études de cas humains et d'essais cliniques randomisés réalisés depuis 1980, année de la découverte de ce facteur relaxant d'origine endothéliale, dénomination qui lui fût attribuée à l;époque.

Constatations principales : Le monoxyde d'azote a des effets pulmonaires et généraux. Le monoxyde d'azote inhalé ne cause pas seulement une vasodilatation pulmonaire sélective, mais il provoque aussi une vasoconstriction pulmonaire des vaisseaux perfusant les alvéoles non ventilées. Les effets généraux de monoxyde d'azote, y compris la modulation de la distribution du débit sanguin, l'augmentation du débit rénal, l'interaction avec la coagulation, la capacité fonctionnelle de la fibrinolyse et des plaquettes, la modification de la réponse inflammatoire, sont décrits et les mécanismes du transport de monoxyde d'azote sont expliqués. On discute également de la toxicité de monoxyde d'azote inhalé.

Conclusion : Les multiples effets de l'oxyde nitrique inhalé expliquent l'intérêt qu'il présente comme médication pulmonaire et extrapulmonaire.

I N 1980, Furchgott and Zawadzki ${ }^{1}$ discovered that endothelial cells stimulated by acetylcholine released a vasodilator. Initially named endothelium-derived relaxing factor, its real nature was established several years later, and the molecule was identified as nitric oxide $(\mathrm{NO}){ }^{2,3}$ Over the past two decades, many of NO's biological mechanisms and therapeutic indications have been elucidated. This review summarizes the biological effects of NO.

\section{Synthesis of NO}

\section{Endogenous $\mathrm{NO}$}

Endogenous NO is synthesized by NO synthase (NOS), which combines $\mathrm{O}_{2}$ with L-arginine to produce NO and L-citrulline. ${ }^{4,5}$ The reaction requires nicotinamide adenine dinucleotide phosphate, flavin adenine dinucleotide, flavin mononucleotide, and tetrahydrobiopterin as cofactors. ${ }^{6,7}$ Three types of NOS have been cloned: type I (neuronal or nNOS), type II (inducible or iNOS), and type III (endothelial or eNOS). Neuronal NOS and eNOS are constitutive calcium calmodulin-dependent enzymes and produce $\mathrm{NO}$ in nanomolar concentrations when activated by different agonists that increase intracellular calcium. Two isoforms of nNOS have been documented by antisense mapping. ${ }^{8}$ Inducible NOS is synthesized in

From the Department of Anesthesiology, l'Hôpital Notre-Dame du CHUM, Université de Montréal, Montréal, Québec, Canada. Address correspondence to: Dr. Gilbert Blaise, Laboratoire d'Anesthésie, Pavillon Deschamps, Local FS-1136, Hôpital Notre-Dame du CHUM, 1560, rue Sherbrooke est, Montréal, Québec H2L 4M1, Canada. Phone: 514-890-8202; E-mail: blaisegil@sympatico.ca This research is supported by a grant to Dr. Gilbert Blaise from the Canadian Institute of Health Research. The authors do not have any funding from the manufacturers or suppliers of NO.

Submitted March 11, 2002.

1st revision submitted August 14, 2002.

2nd revision accepted February 6, 2003. 
response to several inflammatory mediators and produces NO in micromolar concentrations in a calciumindependent manner. ${ }^{9,10}$

In vivo synthesis of $\mathrm{NO}$ occurs in the lungs in the vascular endothelium, epithelial cells, ${ }^{11}$ nerve cells, ${ }^{12}$ smooth muscle cells, and inflammatory cells such as macrophages. In addition, the cells of the upper airways, especially in the nose and paranasal sinuses, ${ }^{13,14-17}$ generate large amounts of $\mathrm{NO}$, which is inhaled whenever the patient inspires through the nose.

\section{Commercial production of $\mathrm{NO}$}

In vitro, $\mathrm{NO}$ gas can be produced from the reaction of liquid sulfuric acid $\left(\mathrm{H}_{2} \mathrm{SO}_{4}\right)$ and liquid sodium nitrite $\left(\mathrm{NaNO}_{2}\right)$, and then purified of nitrogen $\left(\mathrm{N}_{2}\right)$, nitrous oxide $\left(\mathrm{N}_{2} \mathrm{O}\right)$ and carbon dioxide $\left(\mathrm{CO}_{2}\right)$ :

$$
\mathrm{H}_{2} \mathrm{SO}_{4}+2 \mathrm{NaNO}_{2} \rightarrow \mathrm{NO}+\mathrm{NO}_{2}+\mathrm{NaSO}_{4}+\mathrm{H}_{2} \mathrm{O}^{18}
$$

$\mathrm{NO}$ gas can be added to the inspiratory gas flow during the inspiratory phase and delivered to the patient at a precise concentration. Several companies have developed very efficient NO delivery systems that match NO administration with inspiratory gas flow.

$\mathrm{NO}$ is available in industrial and medical grades. Medical grade NO is higher in purity but is more expensive than industrial grade NO. Currently, most Canadian hospitals use industrial NO from different suppliers; however, at some point, the therapeutic standard will require medical grade $\mathrm{NO}$ gas. Unfortunately, medical grade $\mathrm{NO}$ is only available through the Special Access Program and has not yet received definitive approval from Health Canada.

In Canada, medical grade $\mathrm{NO}$ is available as ViaNOx $^{\mathrm{TM}}-\mathrm{H}$ (Summit Technology Inc.) in C-size cylinders (2.18 L of $800 \mathrm{ppm} \mathrm{NO}$ ) at $\$ 2,728$ Canadian. In the United States and Europe, INO Therapeutics sells a complete package that comprises a delivery apparatus, medical grade $\mathrm{NO}$, staff training, and paramedical and technical support. The company charges for $\mathrm{NO}$ treatment on an hourly basis (US $\$ 150 \cdot \mathrm{hr}^{-1}$ or Euro $150 \cdot \mathrm{hr}^{-1}$ for a maximum of $\left.96 \mathrm{hr}\right) .{ }^{19}$

\section{Biological mechanisms of NO}

NO stimulates soluble guanylate cyclase (sGC) and increases cyclic guanylate monophosphate (cGMP). The latter activates cGMP-dependent protein kinases that are abundant in the cerebellum, smooth and cardiac myocytes, platelets, and leukocytes. ${ }^{20}$ In turn, the kinases mediate the cGMP-induced decrease in intracellular calcium concentration in vascular smooth muscles and produce relaxation and vasodilatation. ${ }^{21}$

\section{Pulmonary effects of $\mathrm{NO}$}

NO has several potentially beneficial effects on pulmonary function by maintaining low pulmonary arterial pressures and sustaining normal vascular permeability. In addition to its vasodilatory effects, recent work in pigs suggests that in vivo NO production is inhibited by a blood-borne inhibitor of NOS (such as asymmetric dextromethylarginine or by direct inhibition of eNOS $)^{22}$ in the presence of inhaled NO (iNO). The effect is greater in hypoxic regions. Thus, iNO may have a dual effect: pulmonary vasodilatation in ventilated regions and pulmonary vasoconstriction in poorly ventilated or hypoxic regions. The overall effect is a decrease in pulmonary arterial pressures, attenuation of ventilation-perfusion mismatch, and improvement in oxygenation. Animal studies show that iNO is particularly effective in reversing hypoxia-induced pulmonary hypertension but is less potent in vasoconstrictorinduced pulmonary hypertension from thromboxane $\mathrm{A}_{2}$ or protamine-heparin reaction. ${ }^{23,24}$

In addition to its effect on the pulmonary vasculature, NO has some antibacterial actions provided through formation of reactive nitrogen oxides like peroxynitrite. ${ }^{25} \mathrm{NO}$ also modulates ciliary beat frequency ${ }^{26}$ and can inhibit or stimulate mucus secretion. ${ }^{27,28}$

Inhaled NO has been considered for a long time to be a selective pulmonary vasodilator that has no clinically significant effect on blood pressure and cardiac output. Its selective action results from the fixation of iNO to the heme moiety of the hemoglobin molecule after passing through the pulmonary vessel wall. NO is then oxidized to $\mathrm{NO}_{2}$ and $\mathrm{NO}_{3}$. Hemoglobin is transformed to methemoglobin, which is secondarily reduced to hemoglobin by methemoglobin reductase. ${ }^{29,30}$ Although iNO has no systemic hemodynamic effects, it does have extra-pulmonary activity.

\section{Effects of NO on coagulation}

NO interferes with platelet and leukocyte functions, ${ }^{31}$ fibrinolysis, ${ }^{32}$ restenosis, ${ }^{33}$ and reperfusion injury ${ }^{34}$ by inhibiting expression of adhesion molecules at leukocyte surfaces and by activating sGC, which lead to rapid increase in platelet cGMP and inhibition of platelet aggregation. NO also inhibits vascular smooth muscle cell proliferation, leading to decreased neointimal hyperplasia. ${ }^{35}$

\section{Effects on inflammation}

The mechanisms of action of NO on the inflammatory process are complex. Conflicting data on the effect of iNO on the pulmonary inflammatory response have been published, as both increases and decreases in inflammatory mediators have been observed in 
patients suffering from severe acute respiratory distress syndrome treated by iNO. ${ }^{36-40}$ The different effects depend on the concentration of $\mathrm{NO}$, the local oxidation-reduction potential, and the presence of other inflammatory mediators and oxygen-derived free radicals. ${ }^{41,42}$ Low amounts of NO derived from eNOS and nNOS are believed to be beneficial, whereas large quantities produced by iNOS contribute to the injury observed in different experimental models of inflammation. However, inhibition of iNOS may exacerbate injury in certain situations, suggesting that iNOS-derived NO may be protective as well.

$\mathrm{NO}$ interferes with nuclear transcription factor- $\kappa \mathrm{B}$ $(\mathrm{NF}-\kappa \mathrm{B})$ and inhibits tumour necrosis factor (TNF) alpha activation of NF- $\kappa B$ through stabilization of I $\kappa \mathrm{B}-\alpha$ and increased I $\mathrm{I} \mathrm{B}-\alpha$ gene expression. NO modulates leukocyte-endothelial interactions and the infiltration of activated leukocytes into sites of inflammation by inhibiting the expression of adhesion molecules. ${ }^{43-47} \mathrm{NO}$ can have pro-inflammatory effects by increasing the expression of inflammatory proteins such as TNF- $\alpha$ and cyclooxygenase- $2 .{ }^{48,49}$

Inhaled NO does not decrease the inflammatory response when inflammation is already in process and may increase peroxynitrite production, but its use very early or before the onset of inflammation may attenuate pulmonary and extra-pulmonary inflammatory processes. In acute cardiopulmonary bypass-induced pulmonary inflammation in pigs, iNO modulates the pulmonary inflammatory reaction by preventing pulmonary vasoactive responses and by preventing the production of inflammatory intermediates, such as matrix metalloproteinases. ${ }^{50,51}$ Inhaled $\mathrm{NO}$, given early but not late in the disease process, can prevent pulmonary endothelial dysfunction that follows endotoxin injection. ${ }^{52}$ Inhaled NO reduces myocardial dysfunction in endotoxemic rats ${ }^{53}$ and can prevent pulmonary hypertension after congenital heart defect repair in humans. ${ }^{54}$ If these observations are confirmed by clinical trials, prophylactic iNO at non-toxic concentrations could be an excellent medication to reduce excessive inflammatory responses that follow medical or surgical pathologies.

\section{Systemic vascular effects of $N O$}

At the peripheral level, $\mathrm{NO}$ and $\mathrm{O}_{2}$ are released as hemoglobin changes its configuration from the relaxed, (high $\mathrm{NO}$ and high $\mathrm{O}_{2}$ content) to the tense (low NO and low $\mathrm{O}_{2}$ content) form. NO is transported from the hemoglobin molecule through the cell membrane via anion exchange protein. ${ }^{55,56} \mathrm{~A}$ number of intermediates and mechanisms have been described to explain the transfer of $\mathrm{NO}$ fixed to proteins to cytosolic sGC, the NO receptor. ${ }^{57}$ Plasmatic nitrite can also be reduced to $\mathrm{NO}$ in an acidic milieu. ${ }^{58}$ Although iNO has no clinically significant global effect on systemic hemodynamics, it has a differential action on the circulation, decreasing blood flow if the NO sGC pathway is normal, and increasing it if NO sGC is inhibited, as can happen in arteriosclerosis. ${ }^{59} \mathrm{It}$ can also decrease endothelium-dependent relaxation in the rat aorta (personal communication; Éric Troncy) and in the pulmonary circulation.

\section{Other effects of $N O$}

Inhaled NO increases urine output without changing systemic hemodynamic parameters in pigs ${ }^{60}$ rats, and humans. ${ }^{61}$

\section{Adverse effects of NO}

\section{Toxicity}

Toxicity from iNO results from the formation of methemoglobin, $\mathrm{NO}_{2}$, and peroxynitrite: ${ }^{62}$

$$
\begin{aligned}
& -\mathrm{Hb}\left(\mathrm{Fe}^{2+}\right)+\mathrm{NO} \rightarrow \mathrm{MetHb}\left(\mathrm{Fe}^{3+}\right)+\mathrm{NO}_{3} \\
& -2 \mathrm{NO}+\mathrm{O}_{2} \rightarrow 2 \mathrm{NO}_{2} \\
& -\mathrm{NO}+\mathrm{O}_{2} \rightarrow \mathrm{ONOO}^{-}
\end{aligned}
$$

Methemoglobinemia is generally uncommon as methemoglobin is catalyzed by red cell methemoglobin reductase, assuming the iNO concentration, pulse oximetry and clinical signs (e.g., cyanosis, dyspnea) are effectively monitored and the NO concentration is maintained within $80 \mathrm{ppm}$. Young children deficient in methemoglobin reductase may be at increased risk.

$\mathrm{NO}$ can be oxidized to $\mathrm{NO}_{2}$, a potent oxidant. ${ }^{63,64}$ Concomitant administration of high iNO concentration $(>100 \mathrm{ppm})$ and high $\mathrm{FIO}_{2}$ will accelerate this reaction. The upper level of acceptable exposure $\mathrm{iNO}_{2}$ in humans is $2 \mathrm{ppm}$. The estimated one hour $\mathrm{NO}_{2}$ dose resulting in $50 \%$ mortality $\left(\mathrm{LD}_{50}\right)$ among humans is $174 \mathrm{ppm}$, and short-term exposure $>150$ ppm $\mathrm{NO}_{2}$ is generally fatal.

$\mathrm{NO}$ reacts with superoxide anion $\left(\mathrm{O}_{2}^{-}\right)$to produce peroxynitrite $\left(\mathrm{ONOO}^{-}\right)$, a potent oxidant and proinflammatory mediator. Endogenous peroxynitrite plays an important role in the killing of microorganisms and tumour cells; however, excess exogenous or endogenous peroxynitrite in the lungs has potential adverse pulmonary effects, including surfactant alteration, macromolecular structural changes, metabolic injury, and induction of apoptosis. ${ }^{39,40,65}$

Peroxynitrite is a pulmonary irritant and an irreversible inhibitor of mitochondrial function. It destroys surfactant by lipid peroxidation, prevents further surfactant production by mitochondrial poisoning of alveolar type II cells, ${ }^{66}$ and may consequently 
enhance the tendency to alveolar collapse. It may also damage the pulmonary endothelium ${ }^{67,68}$ and profoundly affect the production of endothelium-derived relaxation factor, leading to pulmonary hypertension and trapping of circulating cells in the pulmonary circulation. ${ }^{69}$ Peroxynitrite can induce DNA breakdown and secondary polyadenyl ribose synthetase activity in order to repair DNA, leading to deficits in energy metabolism. Inhibition of polyadenyl ribose synthetase has a beneficial effect in different inflammatory syndromes such as reperfusion injury, sepsis, and diabetes $;^{70,71}$ activation of polyadenyl ribose synthetase consumes large amounts of adenosine diphosphate and may lead to deficits in energy metabolism.

\section{Rebound pulmonary bypertension and hypoxemia}

Life-threatening increases in pulmonary vascular resistance have been noted on acute withdrawal of iNO. Most studies have demonstrated that eNOS levels in the pulmonary vascular endothelium remain unchanged during iNO withdrawal, suggesting that inactivation or down-regulation of eNOS is one of the mechanisms of rebound pulmonary hypertension. ${ }^{72,73}$ Inhaled NO also increases plasma endothelin-1 concentrations without enhancing gene expression in lamb. Endothelin-1 receptor blockade prevents the increase in pulmonary vascular resistance after $\mathrm{NO}$ withdrawal, indicating a role for endothelin- 1 in rebound pulmonary hypertension. ${ }^{74}$ In lamb, reduced NOS activity, associated with iNO therapy, may involve endothelin- 1 receptor-mediated $\mathrm{O}_{2}$ - production. ${ }^{75} \mathrm{NO}$ may stimulate xanthine oxidase and cause an increase in cellular $\mathrm{O}_{2}^{-}$generation. A reaction between $\mathrm{NO}$ and $\mathrm{O}_{2}$ - would produce peroxynitrite, which could then inactivate eNOS protein. ${ }^{72,74,76}$ Endothelin-1 receptor antagonists may prevent rebound pulmonary hypertension by protecting endogenous eNOS activity during iNO therapy. ${ }^{74}$

To prevent rebound pulmonary hypertension, iNO should be tapered off progressively without any attempt to terminate it if $\mathrm{FIO}_{2}$ is higher than $50 \%$. A decrease in oxygenation induced by $\mathrm{NO}$ withdrawal may be compensated by an increase in $\mathrm{FIO}_{2}$. In our clinical trial, we determined the daily optimal concentration of iNO (the lowest concentration with the greatest effect on oxygenation) and found that, as patients improved, the required iNO concentrations decreased. ${ }^{77}$ Weaning from iNO was undertaken when optimal iNO concentration was $0.5 \mathrm{ppm}$ and was successful in each patient. If weaning from iNO induces a large increase in pulmonary pressure with a decrease in oxygenation, it should be restarted and more progressive weaning should be undertaken. Drugs that poten- tiate or increase the production of endogenous $\mathrm{NO}$ could be useful in difficult cases.

\section{Alternatives to inhaled NO}

Pulmonary vasodilatation can be achieved with soluble NO donors, phosphodiesterase inhibitors, prostaglandins, and endothelin receptor antagonists. NO nucleophile adducts, and NONOate (2-(dimethylamino) ethylputreanine-NO) have been used in animal models of pulmonary hypertension ${ }^{78,79}$ and compared to inhaled sodium nitroprusside 80,81 and inhaled nitroglycerine. ${ }^{82,83}$ The duration of action of these medications is longer than iNO and their pulmonary selectivity has been questioned, particularly for the NONOates. Currently, only inhaled sodium nitroprusside has been used in humans. ${ }^{84}$

The effect of iNO can be enhanced by phosphodiesterase $\mathrm{V}$ inhibitors (dypiridamol, zaprinast, sildenafil), which block cGMP degradation. ${ }^{85,86}$ These medications can be inhaled and produce vasodilatation by enhancing the effect of endogenous $\mathrm{NO}$; this is particularly true for sildenafil, which is not only a phosphodiesterase $\mathrm{V}$ inhibitor but also induces smooth muscle cells hyperpolarization through its action on potassium channels. Sildenafil could become one of the first treatments in pulmonary hypertension. ${ }^{87}$ Milrinone and amrinone, phosphodiesterase III inhibitors that specifically metabolize cyclic adenosine monophosphate (cAMP), may potentiate iNO's effect in an additive fashion as they act on different pathways. Milrinone has been used in inhalation therapy in humans. ${ }^{88}$

Prostaglandin El and I2 increase cAMP and reduce pulmonary hypertension; iv prostacyclin (prostaglandin I2) is still the classical treatment of pulmonary hypertension. The pulmonary selectivity of these medications may be enhanced by inhalation. Bolus doses between 15 and $30 \mu \mathrm{g}$ of inhaled prostacyclin have been administered in humans with potent effects on pulmonary pressure and oxygenation. ${ }^{89,90}$ Inhaled NO and prostacyclin may have additive actions as both medications act through different vasodilatory pathways. ${ }^{91}$

Endothelin- 1 is a potent vasoconstrictor released by endothelial cells in the pathophysiology of pulmonary hypertension. Bosenstan, a nonspecific endothelin-1 receptor antagonist, has been approved as a medication for primary pulmonary hypertension and will be available in the future.

\section{Conclusion}

Since the first use of iNO, its mechanisms of action have become clearer, and its indications have changed. Initially recognized as a pulmonary medication, data 
indicate that the extra-pulmonary effects of INO are significant and could be of clinical benefit. The mechanisms of iNO on pulmonary and extra-pulmonary inflammation are being studied and iNO could be an important adjuvant to modulate the inflammation that is induced by major surgery and trauma. The possible toxicity of iNO could be negated by medications such as antioxidants and reactive oxygen species scavengers.

\section{References}

1 Furchgott RF, Zawadzki JV. The obligatory role of endothelial cells in the relaxation of arterial smooth muscle by acetylcholine. Nature 1980; 288: 373-6.

2 Ignarro LJ, Buga GM, Wood KS, Byrns RE, Chaudhuri $G$. Endothelium-derived relaxing factor produced and released from artery and vein is nitric oxide. Proc Natl Acad Sci USA 1987; 84: 9265-9.

3 Palmer RM, Ferrige AG, Moncada S. Nitric oxide release accounts for the biological activity of endothelium-derived relaxing factor. Nature 1987; 327: 524-6.

4 Moncada $S$, Higgs $A$. The L-arginine-nitric oxide pathway. N Engl J Med 1993; 329: 2002-12.

5 Nathan C, Xie $Q W$. Nitric oxide synthases: roles, tolls, and controls. Cell 1994; 78: 915-8.

6 Tiefenbacher CP. Tetrahydrobiopterin: a critical cofactor for eNOS and a strategy in the treatment of endothelial dysfunction? Am J Physiol Heart Circ Physiol 2001; 280: H2484-8.

7 Blaise G. The endothelium at rest. In: Spiess (Ed.). The Relationship Between Coagulation, Inflammation, and Endothelium - A Pyramid Towards Outcome. Baltimore: Lippincott Williams \& Wilkins; 2000: 31-78.

8 Kolesnikov $\Upsilon A$, Pan $\Upsilon X$, Babey AM, Jain $S$, Wilson $R$, Pasternak $G W$. Functionally differentiating two neuronal nitric oxide synthase isoforms through antisense mapping: evidence for opposing NO actions on morphine analgesia and tolerance. Proc Natl Acad Sci USA 1997; 94: 8220-5.

9 Lin HW, Anand A, Bloch K, Christiani D, Kradin R. Expression of inducible nitric oxide synthase by macrophages in rat lung. Am J Respir Crit Care Med 1997; 156: 223-8.

10 Nussler AK, Billiar TR. Inflammation, immunoregulation, and inducible nitric oxide synthase. J Leukoc Biol 1993; 54: 171-8.

11 Guo FH, De Raeve HR, Rice TW, Stuehr DJ, Thunnissen FB, Erzurum SC. Continuous nitric oxide synthesis by inducible nitric oxide synthase in normal human airway epithelium in vivo. Proc Natl Acad Sci USA 1995; 92: 7809-13.

12 Belvisi MG, Stretton CD, Yacoub M, Barnes PJ. Nitric oxide is the endogenous neurotransmitter of bron- chodilator nerves in humans. Eur J Pharmacol 1992; 210: 221-2.

13 Lundberg JO, Lundberg JM, Settergren G, Alving K, Weitzberg $E$. Nitric oxide, produced in the upper airways, may act in an 'aerocrine' fashion to enhance pulmonary oxygen uptake in humans. Acta Physiol Scand 1995; 155: 467-8.

14 Chambers DC, Carpenter DA, Ayres JG. Exchange dynamics of nitric oxide in the human nose. J Appl Physiol 2001; 91: 1924-30.

15 Dillon WC, Hampl V, Shultz PJ, Rubins JB, Archer SL. Origins of breath nitric oxide in humans. Chest 1996; 110: 930-8.

16 Hogman M, Frostell CG, Hedenstrom H, Hedenstierna $G$. Inhalation of nitric oxide modulates adult human bronchial tone. Am Rev Respir Dis 1993; 148: 1474-8.

17 Lundberg JO, Settergren G, Gelinder S, Lundberg JM, Alving $K$, Weitzberg $E$. Inhalation of nasally derived nitric oxide modulates pulmonary function in humans. Acta Physiol Scand 1996; 158: 343-7.

18 Francoe $M$, Troncy E, Blaise G. Inhaled nitric oxide: technical aspects of administration and monitoring. Crit Care Med 1998; 26: 782-96.

19 Subbedar NV, Jaubari P, Natarajan R. Cost of inhaled nitric oxide therapy in neonates. Lancet 2002; 359: 1781-2.

20 Lucas KA, Pitari GM, Kazerounian S, et al. Guanylyl cyclases and signaling by cyclic GMP. Pharmacol Rev 2000; 52: 375-414.

21 Hanafy KA, Krumenacker JS, Murad F. NO, nitrotyrosine, and cyclic GMP in signal transduction. Med Sci Monit 2001; 7: 801-19.

22 Leiper J, Vallance P. Biological significance of endogenous methylarginines that inhibit nitric oxide synthases. Cardiovasc Res 1999; 43: 542-8.

23 Frostell C, Fratacci MD, Wain JC, Jones R, Zapol WM. Inhaled nitric oxide. A selective pulmonary vasodilator reversing hypoxic pulmonary vasoconstriction.

Circulation 1991; 83: 2038-47.

24 Van Obbergh LJ, Charbonneau M, Blaise G. Combination of inhaled nitric oxide with i.v. nitroglycerin or with a prostacyclin analogue in the treatment of experimental pulmonary hypertension. Br J Anaesth 1996; 77: 227-31.

25 Alam MS, Akaike T, Okamoto S, et al. Role of nitric oxide in host defense in murine salmonellosis as a function of its antibacterial and antiapoptotic activities. Infect Immun 2002; 70: 3130-42.

26 Jain B, Rubinstein I, Robbins RA, Leise KL, Sisson JH. Modulation of airway epithelial cell ciliary beat frequency by nitric oxide. Biochem Biophys Res Commun 1993; 191: 83-8. 
27 Ramnarine SI, Khawaja AM, Barnes PJ, Rogers DF. Nitric oxide inhibition of basal and neurogenic mucus secretion in ferret trachea in vitro. Br J Pharmacol 1996; 118: 998-1002.

28 Nagaki M, Shimura MN, Irokawa T, Sasaki T, Shirato $K$. Nitric oxide regulation of glycoconjugate secretion from feline and human airways in vitro. Respir Physiol 1995; 102: 89-95.

29 Higenbottam T, Siddons T, Demoncheaux E. A therapeutic role for chronic inhaled nitric oxide? Lancet 2000; 356: 446-7.

30 Fratacci MD, Frostell CG, Chen TY, Wain JC Jr, Robinson DR, Zapol WM. Inhaled nitric oxide. A selective pulmonary vasodilator of heparin-protamine vasoconstriction in sheep. Anesthesiology 1991; 75: 990-9.

31 Malmros C, Blomquist S, Dahm P, Martensson L, Thorne $J$. Nitric oxide inhalation decreases pulmonary platelet and neutrophil sequestration during extracorporeal circulation in the pig. Crit Care Med 1996; 24: 845-9.

32 Adrie C, Bloch KD, Moreno PR, et al. Inhaled nitric oxide increases coronary artery patency after thrombolysis. Circulation 1996; 94: 1919-26.

33 Russo G, Leopold JA, Loscalzo J. Vasoactive substances: nitric oxide and endothelial dysfunction in atherosclerosis. Vascul Pharmacol 2002; 38: 259-69.

34 Jugdutt BI. Nitric oxide and cardioprotection during ischemia-reperfusion. Heart Fail Rev 2002; 7 : 391-405.

35 Leopold JA, Loscalzo J. New developments in nitrosovasodilator therapy. Vasc Med 1997; 2: 190-202.

36 Bloomfield GL, Holloway S, Ridings PC, et al. Pretreatment with inhaled nitric oxide inhibits neutrophil migration and oxidative activity resulting in attenuated sepsis-induced acute lung injury. Crit Care Med 1997; 25: 584-93.

37 Chollet-Martin S, Gatecel C, Kermarrec N, GougerotPocidalo MA, Payen DM. Alveolar neutrophil functions and cytokine levels in patients with the adult respiratory distress syndrome during nitric oxide inhalation. Am J Respir Crit Care Med 1996; 153: 985-90.

38 Rubbo H, Radi R, Anselmi D, et al. Nitric oxide reaction with lipid peroxyl radicals spares $\alpha$-tocopherol during lipid peroxidation. Greater oxidant protection from the pair nitric oxide $/ \alpha$-tocopherol than $\alpha$-tocopherol/ascorbate. J Biol Chem 2000; 275: 10812-8.

39 Baldus $S$, Castro L, Eiserich JP, Freeman BA. Is NO news bad news in acute respiratory distress syndrome? Am J Respir Crit Care Med 2001; 163: 308-10.

40 Sittipunt C, Steinberg KP, Ruzinski JT, et al. Nitric oxide and nitrotyrosine in the lungs of patients with acute respiratory distress syndrome. Am J Respir Crit Care Med 2001; 163: 503-10.

41 Colasanti $M$, Persichini $T$. Nitric oxide: an inhibitor of
NF- $\kappa \mathrm{B} /$ Rel system in glial cells. Brain Res Bull 2000; 52: 155-61.

42 Laroux FS, Pavlick KP, Hines IN, et al. Role of nitric oxide in inflammation. Acta Physiol Scand 2001; 173: 113-8.

43 Khan BV, Harrison DG, Olbrych MT, Alexander RW, Medford RM. Nitric oxide regulates vascular cell adhesion molecule 1 gene expression and redox-sensitive transcriptional events in human vascular endothelial cells. Proc Natl Acad Sci USA 1996; 93: 9114-9.

44 Kupatt C, Weber C, Wolf DA, Becker BF, Smith TW, Kelly $R A$. Nitric oxide attenuates reoxygenationinduced ICAM-1 expression in coronary microvascular endothelium: role of NFкB. J Mol Cell Cardiol 1997; 29: 2599-609.

45 Shin WS, Hong $\Upsilon H$, Peng HB, De Caterina R, Libby $P$, Liao JK. Nitric oxide attenuates vascular smooth muscle cell activation by interferon- $\gamma$. The role of constitutive NF- $\kappa \mathrm{B}$ activity. J Biol Chem 1996; 271 : 11317-24.

46 Spiecker M, Peng HB, Liao JK. Inhibition of endothelial vascular cell adhesion molecule- 1 expression by nitric oxide involves the induction and nuclear translocation of IкB $\alpha$. J Biol Chem 1997; 272: 30969-74.

47 Spiecker M, Darius H, Kaboth K, Hubner F, Liao JK. Differential regulation of endothelial cell adhesion molecule expression by nitric oxide donors and antioxidants. J Leukoc Biol 1998; 63: 732-9.

48 Perkins DJ, Kniss DA. Blockade of nitric oxide formation down-regulates cyclooxygenase-2 and decreases $\mathrm{PGE}_{2}$ biosynthesis in macrophages. J Leukoc Biol 1999; 65: 792-9.

49 Sheffler LA, Wink DA, Melillo G, Cox GW. Exogenous nitric oxide regulates IFN- $\gamma$ plus lipopolysaccharideinduced nitric oxide synthase expression in mouse macrophages. J Immunol 1995; 155: 886-94.

50 Hubert BP, Blaise GA. Inhaled NO given perioperatively improves oxygenation and decreases pulmonary arterial resistance following cardiopulmonary bypass in a pig model. Anesthesiology 2001; 95: A-366 (abstract).

51 Hubert BP, Radomski M, Blaise GA. Does inhaled nitric oxide (inhNO) affect matrix-metalloproteinase (MMP) concentration in bronchoalveolar lavage fluid (BAL) after cardiopulmonary bypass (CPB)? Anesthesiology 2001; 95: A-440 (abstract).

52 Friese RS, Fullerton DA, McIntyre RC Jr, et al. NO prevents neutrophil-mediated pulmonary vasomotor dysfunction in acute lung injury. J Surg Res 1996; 63: 23-8.

53 Neviere R, Guery B, Mordon S, et al. Inhaled NO reduces leukocyte-endothelial cell interactions and myocardial dysfunction in endotoxemic rats. Am J Physiol Heart Circ Physiol 2000; 278: H1783-90. 
54 Miller OI, Tang SF, Keech A, Pigott NB, Beller E, Celermajer DS. Inhaled nitric oxide and prevention of pulmonary hypertension after congenital heart surgery: a randomised double-blind study. Lancet 2000; 356: 1464-9.

55 Gross SS. Vascular biology. Targeted delivery of nitric oxide. Nature 2001; 409: 577-8.

56 Pawloski JR, Hess DT, Stamler JS. Export by red blood cells of nitric oxide bioactivity. Nature 2001; 409 : 622-6.

57 Ramachandran N, Root P, Jiang XM, Hogg PJ, Mutus $B$. Mechanism of transfer of NO from extracellular $S$ nitrosothiols into the cytosol by cell-surface protein disulfide isomerase. Proc Natl Acad Sci USA 2001; 98 : 9539-44.

58 Modin A, Bjorne H, Herulf M, Alving K, Weitzberg E, Lundberg JO. Nitrite-derived nitric oxide: a possible mediator of 'acidic-metabolic' vasodilation. Acta Physiol Scand 2001; 171: 9-16.

59 Cannon RO III, Schechter AN, Panza JA, et al. Effects of inhaled nitric oxide on regional blood flow are consistent with intravascular nitric oxide delivery. J Clin Invest 2001; 108: 279-87.

60 Troncy E, Francoeur M, Salazkin I, et al. Extra-pulmonary effects of inhaled nitric oxide in swine with and without phenylephrine. Br J Anaesth 1997; 79: $631-40$.

61 Wraight WM, Young JD. Renal effects of inhaled nitric oxide in humans. Br J Anaesth 2001; 86: 267-9.

62 Weinberger B, Laskin DL, Heck DE, Laskin JD. The toxicology of inhaled nitric oxide. Toxicol Sci 2001; 59: 5-16.

63 Beckman JS, Koppenol WH. Nitric oxide, superoxide, and peroxynitrite: the good, the bad, and the ugly. Am J Physiol 1996; 271: C1424-37.

64 Pryor WA, Squadrito GL. The chemistry of peroxynitrite: a product from the reaction of nitric oxide with superoxide. Am J Physiol 1995; 268: L699-722.

65 van der Vliet A, Eiserich JP, Shigenaga MK, Cross CE. Reactive nitrogen species and tyrosine nitration in the respiratory tract. Epiphenomena or a pathobiologic mechanism of disease? Am J Respir Crit Care Med 1999; 160: 1-9.

66 Haddad IY, Zhu S, Crow J, Barefield E, Gadilhe T, Matalon S. Inhibition of alveolar type II cell ATP and surfactant synthesis by nitric oxide. Am J Physiol 1996; 270: L898-906.

67 Knepler JL Jv, Taher LN, Gupta MP, et al. Peroxynitrite causes endothelial cell monolayer barrier dysfunction. Am J Physiol Cell Physiol 2001; 281: C1064-75.

68 Szabo C, Cuzzocrea S, Zingarelli B, O'Connor $M$, Salzman $A L$. Endothelial dysfunction in a rat model of endotoxic shock. Importance of the activation of poly
(ADP-ribose) synthetase by peroxynitrite. J Clin Invest 1997; 100: 723-35.

69 Zouki C, Zhang SL, Chan JS, Filep JG. Peroxynitrite induces integrin-dependent adhesion of human neutrophils to endothelial cells via activation of the Raf1/MEK/Erk pathway. FASEB J 2001; 15: 25-7.

70 Soriano FG, Pacher P, Mabley J, Liaudet L, Szabo C. Rapid reversal of the diabetic endothelial dysfunction by pharmacological inhibition of poly(ADP-ribose) polymerase. Circ Res 2001; 89: 684-91.

71 Szabo C, Billiar TR. Novel roles of nitric oxide in hemorrhagic shock. Shock 1999; 12: 1-9.

72 Black SM, Heidersbach RS, McMullan DM, Bekker JM, Johengen MJ, Fineman JR. Inhaled nitric oxide inhibits NOS activity in lambs: potential mechanism for rebound pulmonary hypertension. Am J Physiol 1999; 277: H1849-56.

73 Dotsch J, Demirakca S, Zepf K, Hanze J, Parida S, Rascher $W$. Recovery from withdrawal of inhaled nitric oxide and kinetics of nitric oxide-induced inhibition of nitric oxide synthase activity in vitro. Intensive Care Med 2000; 26: 330-5.

74 McMullan DM, Bekker JM, Johengen MJ, et al. Inhaled nitric oxide-induced rebound pulmonary hypertension: role for endothelin-1. Am J Physiol Heart Circ Physiol 2001; 280: H777-85.

75 Wedgwood S, McMullan DM, Bekker JM, Fineman JR, Black SM. Role for endothelin-1-induced superoxide and peroxynitrite production in rebound pulmonary hypertension associated with inhaled nitric oxide therapy. Circ Res 2001; 89: 357-64.

76 Sheeby AM, Burson MA, Black SM. Nitric oxide exposure inhibits endothelial NOS activity but not gene expression: a role for superoxide. Am J Physiol 1998; 274: L833-41.

77 Troncy E, Collet JP, Shapiro S, et al. Inhaled nitric oxide in acute respiratory distress syndrome. A pilot randomized controlled study. Am J Respir Crit Care Med 1998; 157: 1483-8.

78 Jacobs BR, Brilli RJ, Ballard ET, Passerini DJ, Smith $D J$. Aerosolized soluble nitric oxide donor improves oxygenation and pulmonary hypertension in acute lung injury. Am J Respir Crit Care Med 1998; 158: 1536-42.

79 Brilli RJ, Krafte-Jacobs B, Smith DJ, Passerini D, Moore $L$, Ballard ET. Aerosolization of novel nitric oxide donors selectively reduce pulmonary hypertension. Crit Care Med 1998; 26: 1390-6.

80 Adrie C, Ichinose F, Holzmann A, Keefer L, Hurford WE, Zapol WM. Pulmonary vasodilation by nitric oxide gas and prodrug aerosols in acute pulmonary hypertension. J Appl Physiol 1998; 84: 435-41.

81 Meadow W, Rudinsky B, Bell A, Hipps R. Effects of 
nebulized nitroprusside on pulmonary and systemic hemodynamics during pulmonary hypertension in piglets. Pediatr Res 1998; 44: 181-6.

82 Schutte H, Grimminger F, Otterbein J, et al. Efficiency of aerosolized nitric oxide donor drugs to achieve sustained pulmonary vasodilation. J Pharmacol Exp Ther 1997; 282: 985-94.

83 Gong F, Shiraishi H, Kikuchi $\Upsilon$, et al. Inhalation of nebulized nitroglycerin in dogs with experimental pulmonary hypertension induced by U46619. Pediatr Int 2000; 42: 255-8.

84 Palhares DB, Figueiredo CS, Moura AJ. Endotracheal inhalatory sodium nitroprusside in severely hypoxic newborns. J Perinat Med 1998; 26: 219-24.

85 Ichinose F, Adrie C, Hurford WE, Bloch KD, Zapol $W M$. Selective pulmonary vasodilation induced by aerosolized zaprinast. Anesthesiology 1998; 88: 410-6.

86 Ichinose F, Erana-Garcia J, Hromi J, et al. Nebulized sildenafil is a selective pulmonary vasodilator in lambs with acute pulmonary hypertension. Crit Care Med 2001; 29: 1000-5.

87 Michelakis E, Tymchak W, Lien D, Webster L, Hashimoto $K$, Archer $S$. Oral sildenafil is an effective and specific pulmonary vasodilator in patients with pulmonary arterial hypertension. Comparison with inhaled nitric oxide. Circulation 2002; 105: 2398-403.

88 Haraldsson A, Kieler-Jensen N, Ricksten SE. The additive pulmonary vasodilatory effects of inhaled prostacyclin and inhaled milrinone in postcardiac surgical patients with pulmonary hypertension. Anesth Analg 2001; 93: 1439-45.

89 Haraldsson A, Kieler-Jensen N, Nathorst-Westfelt U, Bergh CH, Ricksten SE. Comparison of inhaled nitric oxide and inhaled aerosolized prostacyclin in the evaluation of heart transplant candidates with elevated pulmonary vascular resistance. Chest 1998; 114: 780-6.

90 Hoeper MM, Olschewski H, Ghofrani HA, et al. A comparison of the acute hemodynamic effects of inhaled nitric oxide and aerosolized iloprost in primary pulmonary hypertension. German PPH study group. J Am Coll Cardiol 2000; 35: 176-82.

91 Hill LL, Pearl RG. Combined inhaled nitric oxide and inhaled prostacyclin during experimental chronic pulmonary hypertension. J Appl Physiol 1999; 86:

1160-4. 